\title{
DOES EUROPEAN UNEMPLOYMENT \\ PROP UP AMERICAN WAGES?
}

Donald R. Davis

Working Paper 5620

\section{NATIONAL BUREAU OF ECONOMIC RESEARCH 1050 Massachusetts Avenue \\ Cambridge, MA 02138 \\ June 1996}

I would like to acknowledge, without implication, the helpful comments of Richard Brecher, Carolyn Evans, John Leahy, Howard Shatz, David Weinstein, and Jeff Williamson. I am also grateful for the support for this project from the Harvard Institute for International Development. This paper is part of NBER's research program in International Trade and Investment. Any opinions expressed are those of the author and not those of the National Bureau of Economic Research.

(C) 1996 by Donald R. Davis. All rights reserved. Short sections of text, not to exceed two paragraphs, may be quoted without explicit permission provided that full credit, including (C) notice, is given to the source. 
NBER Working Paper 5620

June 1996

\title{
DOES EUROPEAN UNEMPLOYMENT \\ PROP UP AMERICAN WAGES?
}

\begin{abstract}
We consider trade between a flexible wage America and a rigid real wage Europe. In a benchmark case, a move from autarky to free trade doubles the European unemployment rate, while it raises the American unskilled wage to the high European level. Entry of the unskilled "South" to world markets raises unemployment in Europe. But Europe's commitment to the high wage completely insulates America from the shock. Immigration to America raises American income, but lowers European income dollar-for-dollar, while European unemployment rises onefor-one. We consider a stylized game of the choice of factor market institutions. Mitterand's Europe chooses a high minimum wage and Reagan's America chooses a flexible wage for the unskilled. Paradoxically, unskilled workers are worse off in Europe. Trade equalizes wages, but Europeans bear all of the unemployment required to sustain the high wage.
\end{abstract}

Donald R. Davis

Department of Economics

Littauer Center 229

Harvard University

Cambridge, MA 02138

and NBER 


\section{Does European Unemployment Prop Up American Wages?}

\section{Introduction}

In recent years, factor market developments in the United States and United Kingdom have contrasted sharply with those in continental Europe. In the US and UK, the relative wage of the unskilled has declined significantly. In the span of a decade (1979-89) the relative wage of a US worker in the 90 th percentile to that of one in the 10 th percentile rose by over twenty per cent. [Freeman and Katz (1995)] This rising wage inequality was much less evident in continental Europe. However, unemployment has risen sharply in Europe. The early postwar decades are now thought of as a "Golden Age" for Europe, with unemployment rates of two to three per cent. Beginning in the 1970 s these rates have climbed dramatically, reaching double digits in many of these countries [CEPR (1995)].

An extensive empirical literature has considered the provenance of these factor market developments. The studies are of two principal types [Freeman and Katz (1995)]. The individual country studies provide a rich account of local developments in institutions, factor supplies, and demand conditions. The comparative (cross-country) studies abstract from local idiosyncracies to search for common themes. However, even the comparative studies suffer from an important drawback: they remain a collection of individual stories. They do not pretend to provide a common framework -- and the consistency this enforces -- to provide a unified account.

This suggests the value of a third approach, which may be termed "global." It is, in the first instance, a general equilibrium story. Consistency is enforced by the fact that there is a simultaneous determination of equilibrium in all of the factor markets. Naturally, tractability limits 
the degree of local institutional detail that may be considered. Considering some important differences in factor market institutions will nonetheless be an important feature of such an approach.

However, a global approach is more than just general equilibrium. It aims at a unified explanation of very divergent experience. There are two reasons for seeking such a unified account. First, many of the shocks hitting the industrial "North" are common -- for example, the entry to the integrated world economy of important new trading partners from the newlyindustrializing "South." If we are to believe such accounts, we need to see how these shocks interact with a variety of local institutions. A more subtle -- but by this more important -- reason for considering a global approach is that the consequences even of purely local institutions and shocks often depend crucially on the links to the global market.

The central institutional detail that motivates the present work is the stylized characterization of America as a flexible wage economy, and Europe as an economy in which a variety of institutions -- unions, explicit minimum wages, etc. -- make wages more rigid [Freeman and Katz (1995)]. Thus, we will build a model of world trade between a flexible wage America and a minimum wage Europe. In doing so, we build on the classic work of Brecher (1974a, 1974b). From Krugman (1995) we appropriate the America vs. Europe dichotomy. The present work has two distinctive features. The first is the explicit focus on factor markets in both countries, and particularly on their interaction. The second is the examination of a broader range of shocks to the trading economy than have been considered in earlier work.

\footnotetext{
${ }^{1}$ Another source of common shocks -- those due to global technological change -- is analyzed in Davis (1996a).
} 
This paper confirms that national factor market institutions matter. They profoundly affect global patterns of output, employment, and wages. Surprisingly, though, in our context they have no power in accounting for cross-country differences in the evolution of relative wages. Often forgotten in this context is that even countries with distinctive factor market institutions are linked by world commodity prices and producers' zero profit conditions. Hence an account of the observed wage trends must move beyond an appeal to local institutional differences. A number of potential accounts are considered in this paper, as well as in Davis (1996a,b).

We highlight here some of the more surprising results of the analysis. In a world in which America and Europe have identical endowments, a move from autarky to free trade doubles the European unemployment rate while raising American wages to the European level. In effect, Europe bears the unemployment cost of high wages for both itself and America. In addition, Europe's commitment to maintaining high wages effectively insulates America from external disturbances. Europe, though, is not insulated from shocks in America. For example, a rise in America's labor endowment (e.g. from immigration), which raises American national income, lowers European national income dollar for dollar. It also raises European unemployment one for one.

We also examine the impact of the appearance of newly-industrializing countries (NICs) on the global stage. We find that the European commitment to maintain a high wage wholly insulates America from this shock. In Europe, there is an incipient rise in unemployment. In effect this implies American wages are set in Berlin, not Beijing. ${ }^{2}$ Only if Europe responds with implicit or explicit trade barriers to the NICs is America affected. In this case, the negative employment

\footnotetext{
${ }^{2}$ See Freeman's (1995) paper “Are Your Wages Set in Beijing?"
} 
effects in Europe are mitigated, America sees increased trade with the NICs, and the relative wage of the unskilled in America falls.

When we consider strategic interaction in the choice of factor market institutions, it is possible that two countries which in autarky prefer to maintain a minimum wage will abandon this for a flexible wage under free trade. This could be interpreted as what is sometimes called the "race to the bottom" in labor standards. ${ }^{3}$ However, this is not a necessary, or perhaps even the most likely outcome. As suggested above, conventional wisdom holds that America is closer to a flexible wage economy, while Europe is closer to a minimum wage economy. This is another equilibrium of the game we examine, and gives rise to what we term the Reagan-Mitterrand paradox. In this case, unskilled workers are perversely worse off in the country nominally most committed to protecting their interests. Reagan's America and Mitterrand's Europe share a common wage. But Europe's workers bear all the unemployment that sustains this wage.

This paper has six parts. Section II examines the consequences of differing labor market institutions for countries linked by world commodity trade in homogeneous goods. Section III examines the contrasting impacts on the stylized America and Europe posed by the appearance of newly-industrializing countries. Section IV examines the effects of factor accumulation in our two countries on wages and unemployment. Section V considers the strategic choice of factor market institutions, given our previous results. The final section concludes.

${ }^{3}$ See, for example, the essay by Ralph Nader (1993). 


\section{National Factor Markets and Global Trade}

A. Unemployment in the Global Equilibrium

Our aim is to develop a model of trade between two countries, one of which has flexible wages, while the other imposes a binding minimum wage on unskilled labor. It is convenient to develop this in three stages. The first considers a conventional two sector general equilibrium model of a closed economy and establishes some relations that are key to later analysis. The second introduces a binding minimum wage within the closed economy. Finally, we show the isomorphism between this economy and the two-country trading world of interest.

Consider a closed flexible wage economy. There are two factors of production, skill and labor, available in fixed supply given by $H^{w}$ and $L^{W}$. These are used to produce two goods.

Assume that at any common factor prices, good $X$ is skill intensive relative to the numeraire good, $Y$. Assume that preferences are homothetic, and that both goods are necessary in consumption. Let $w$ be the return to unskilled labor, and $r$ the return to skilled labor. Then the competitive cost conditions insure that for each sector price equals unit cost:

$$
c_{X}(w, r)=P \quad c_{Y}(w, r)=I
$$

Assume that marginal products are always strictly positive. Then flexible wages insure full employment. Factor market clearing requires that employment in the two sectors equal the world endowment:

$$
H_{X}+H_{Y}=H^{W} \quad L_{X}+L_{Y}=L^{W}
$$

By Walras' law, goods market clearing is insured by equality of demand and supply of good $X$.

Three relations are key to our analysis. The first is a relation between the price $P$ in a closed economy and the endowment ratio, $h \equiv H / L$, of that economy. The Heckscher-Ohlin 
theorem insures that a rise in skill abundance reduces the relative price of the skill intensive good. This relation can be expressed as:

$$
\mathrm{P}=\lambda(\mathrm{h}), \quad \text { where } \quad \lambda^{\prime}(\mathrm{h})<0 \text {. }
$$

The second is the Stolper-Samuelson relation between goods prices and factor prices.

Given our assumption that $X$ is always the skill-intensive sector, this defines a monotonic relation, of which we focus on only a part. Let $w$ be the wage of labor in terms of the numeraire. Then by Stolper-Samuelson:

$$
w=\psi(P), \text { where } \psi^{\prime}(P)<0 .
$$

Thus given the endowment ratio of our closed economy, $h^{W}$, we can determine directly the equilibrium goods price in the flexible wage case, $P^{F}=\lambda\left(h^{W}\right)$. Likewise, we can derive the resulting flexible wage, $w^{F}=\psi\left(P^{F}\right)=\psi\left(\lambda\left(h^{T}\right)\right)$, as well as the associated skilled wage. These suffice to establish the basic characteristics of the world equilibrium.

We now introduce within the closed economy a binding minimum wage for the unskilled at rate $w^{*}>w^{F}$. This will be consistent with an equilibrium featuring diversified production if and only if the relative goods price is $P^{*}=\psi^{-1}\left(w^{*}\right)<P^{F}$. However these will be the equilibrium goods and factor prices if and only if employed factors are in the ratio $h^{*}=\lambda^{-1}\left(\psi^{-1}\left(w^{*}\right)\right)>h^{W}$. The flexible rental for skill insures that it will always be fully employed. However with a binding minimum wage, this need not be true for labor. Thus the manner in which relative employed factors rise to $h^{*}$ is for the denominator to fall via unemployed unskilled labor. With $w^{*}$ given, $h^{*}$ is determined, and $H^{W}$ and $L^{W}$ are the fixed world endowments. Let $N$ be the level of labor actually employed. Then simple algebra shows that unemployment in this economy, $U=L^{W}-N$, is given by our third key relation (Brecher): 


$$
U^{*}=L^{W}-H^{W} / h^{*} \equiv \beta\left(h^{*} ; H^{W}, L^{W}\right) \text {, where, } \beta^{\prime}\left(h^{*}\right)>0
$$

These three key relations

characterizing the minimum wage

economy can be considered in Figure 1.

The Heckscher-Ohlin relation, $P=\lambda(h)$, appears in quadrant one. The Stolper-

Samuelson relation, $w=\psi(P)$, appears in quadrant two. Finally, the link between endowments, the employment ratio and

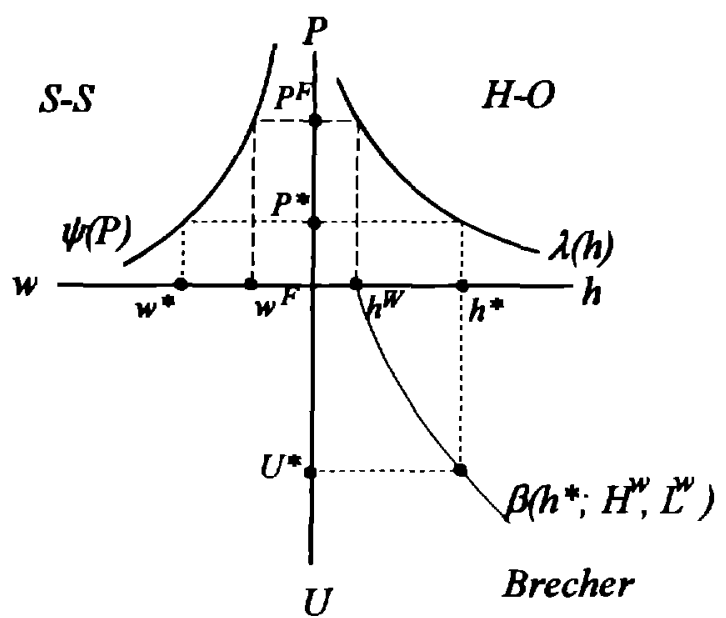
the level of unemployment is depicted in quadrant four. In the flexible wage case, Figure 1 Determination of Equilibrium the employment ratio equals the endowment ratio $h^{W}$. This determines wages, prices and unemployment as $w^{P}, P^{F}$, and zero respectively. In the minimum wage case, the path of determination is different. The given minimum wage $w^{*}>w^{F}$ directly determines the goods price, the employment ratio, and the unemployment level, as $P^{*}, h^{*}$, and $U^{*}$ respectively.

The basic link between the minimum wage and the appearance of unemployment in this economy is very simple. For competitive firms to pay the high wage $w^{*}$, this must be supported by an appropriate goods price $P^{*}$. When the minimum wage binds, the appropriate goods price will be attained only if the relative scarcity of the labor intensive good rises relative to the flexible wage equilibrium. And this will occur only if a sufficient amount of labor is unemployed.

We now establish an isomorphism between the closed economy with a minimum wage and a trading world in which one economy imposes a minimum wage while the other maintains a 
flexible wage. This relies on a concept introduced by Dixit and Norman (1980) known as the integrated equilibrium. This establishes conditions under which trade in goods alone suffices to establish the same world equilibrium as occurs in the closed economy with both goods and factor mobility.

Consider, then, a world of two countries with free trade and zero transport costs. One country -- America -- has flexible wages. The other country -- Europe -- has imposed a minimum wage at the level $w^{*}$. The technologies and preferences in the two countries are identical to those in the closed economy. The technologies are constant returns to scale, while the preferences are identical and homothetic. Let a bar over a variable represent the level of that variable in the integrated equilibrium. Let $\mathrm{i}$ index goods and $\mathrm{j}$ index countries. We can then describe the set of divisions of world endowments among the two countries consistent with replicating the integrated equilibrium. This is called the FPE set, and is described as:

$$
F P E=\left\{\begin{array}{c}
{\left[\left(H^{A m}, L^{A m}\right),\left(H^{E u r}, L^{E u r}\right)\right] \mid \exists \lambda_{i j} \geq 0 \quad \text { such that } \quad \sum_{j} \lambda_{i j}=1,} \\
\left(H^{E u r}, L^{E u r}\right)=\sum_{i} \lambda_{i, E u r}(\bar{H}(i), \bar{L}(i))+\left(0, U^{*}\right) \\
\left(H^{A m}, L^{A m}\right)=\sum_{i} \lambda_{i, A m}(\bar{H}(i), \bar{L}(i)) \quad i=X, Y
\end{array}\right\}
$$

These conditions are very intuitive. If the integrated equilibrium is to be replicated, then world unemployment must be at the same level as in the integrated economy: But unemployment cannot arise in the flexible wage America. Hence Europe must endure the entire integrated equilibrium level of unemployment, $U^{*}$, to maintain the wage $w^{*}$. Beyond this, we need only satisfy the conventional restrictions in terms of employed factors. These require that both countries use the 
integrated equilibrium techniques, that the integrated equilibrium output in both sectors be divided among the countries, and that this exactly exhaust employed factors in the two countries. ${ }^{4}$ The FPE set is depicted as the bold parallelogram in Figure 2.

This allows us to state a key result: Under the conditions stated above, international trade equalizes factor prices between the flexible wage and the minimum wage economies. The proof is simply that under free and costless trade, competitive producers in the two countries face the same goods prices, have the same technologies, and are (at least weakly) diversified. The equality of factor prices then follows directly from the common competitive cost conditions.

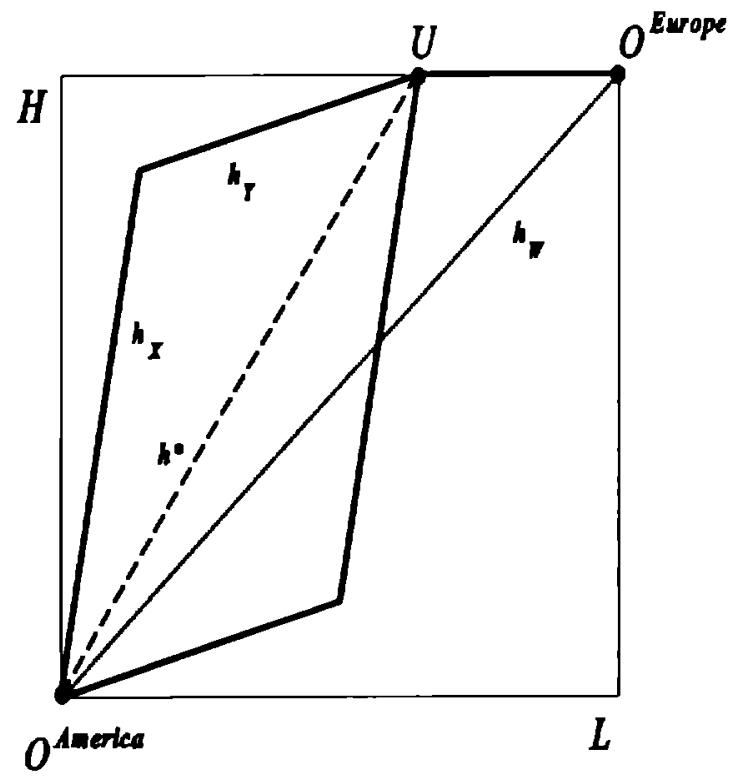

Figure 2 Equilibrium with Unemployment and Factor Price Equalization

4 Since preferences are assumed to be identical and homothetic, the level of spending by the unemployed does not matter for the pattern of world spending. Implicitly, though, we are assuming that any spending by the unemployed is financed via lump sum transfers. The possibility that the finance of the social safety net may itself affect the level of unemployment is considered further in Davis (1996b). 
This is an important result. Even in the face of sharply divergent factor market institutions, free commodity trade in a global market fully equalized factor prices. As we will consider more fully below, this will sharply restrict the nature of shocks that can be appealed to in explaining divergent wage trends between Europe and America.

\section{B. Trade and Unemployment}

We have shown how to construct a model of a trading world between a flexible wage economy and one with a minimum wage. But we have not yet examined what impact trade has on these economies relative to autarky. It is convenient to start with a highly stylized example that establishes a benchmark. Further insight into the workings of this model will be provided by the many comparative statics in later sections.

Take as a benchmark a world in which Europe and America are alike in every respect -endowments, technologies, and preferences. The one exception is that America has a flexible wage, while Europe has a minimum wage at level $w^{*}$, assumed to bind in autarky. As before, technologies are constant returns to scale. For simplicity, assume that preferences of the representative consumer are homothetic.

Figure 3 depicts the salient aspects of the equilibrium. ${ }^{5}$ The technological production frontier, $C C^{\prime}$, is common to America and Europe. In Europe, to support the wage $w^{*}$, the equilibrium price must be $P^{*}$. The composition of demand at $P^{*}$ is given by $\alpha\left(\mathrm{P}^{*}\right)$. Thus under full employment, production at prices $P^{*}$ in Europe would be at $A$, and demand at $A^{\prime}$. This implies an incipient excess demand for $X$, tending to raise $P$ and lower $w$ below $w^{*}$. The incipient fall in

\footnotetext{
${ }^{5}$ This builds on a diagram of Brecher (1974a). See also Krugman (1995).
} 
the wage is instead stanched via a decline in unskilled employment in Europe. With goods prices fixed at $P^{*}$, this is just the Rybczynski theorem in reverse, shifting output along a minimum wageconstrained PPF indicated by $A B$. Autarky equilibrium in Europe is at $E$, at which the constrained supply exactly matches the demand at prices $P^{*}$. The shift of production in Europe from $A$ to $E$ reflects the contraction of employment just necessary to eliminate the excess demand indicated by $A A^{\prime}$. By contrast, in America, the autarky equilibrium features a price $P>P^{*}$ and so an unskilled wage $w<w^{*}$ (not depicted). There is no unemployment in America.

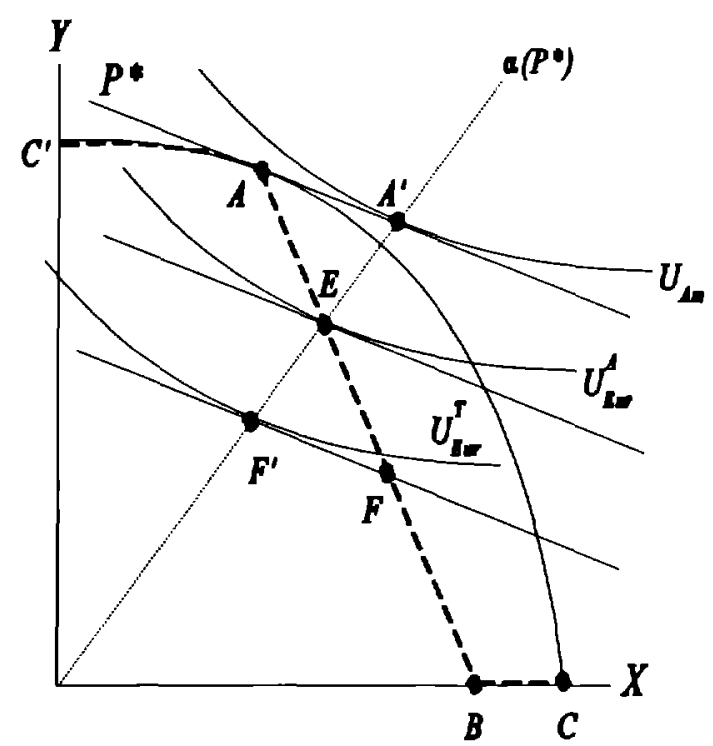

Figure 3 Trade Doubles European Unemployment

Now consider the equilibrium when America and Europe trade freely. In order to support the minimum wage $w^{*}$, Europe still needs to maintain the price $P^{*}$ in equilibrium. At prices $P^{*}$, the American net trade offer is indicated by $A A^{\prime}$. Thus world equilibrium at these prices requires that Europe be willing to make this trade at prices $P^{*}$. This requires that European production be at point $F$, and absorption at $F^{\prime}$. As demand is homothetic, and production linear at all points 
along $A B$, the loss of employment in moving from $\mathrm{E}$ to $\mathrm{F}$ matches the pre-existing unemployment indexed by $\mathrm{AE}^{6}$

This implies a striking contrast between Europe and America in the labor market.

Europe's commitment to a high wage gave rise to unemployment in autarky. In our stylized example the opening of Europe to trade with America doubles European unemployment, as it is forced to absorb the full integrated equilibrium level of unemployment to sustain $w^{*}$ for both. In America, the absence of unemployment in autarky came at the cost to workers of a lower real wage. However once trade commenced, American workers came to share the high European wage even as they suffered none of the unemployment that sustains that wage. The fact that they suffer no unemployment is a consequence of the flexible wage in America. The fact that they nonetheless share the European high wage under trade follows from the fact that trade links goods prices, that both countries remain diversified, and that producers still must meet price equals unit cost conditions. In effect, trade has forced European workers to bear the burden of high unemployment to maintain not only their own high wage, but that in America as well.

How robust is this result? This is most easily illustrated by placing the same information in a framework of export supply and import demand. As we have seen, the minimum wage constraint makes European export supply at price $P^{*}$ multi-valued, corresponding to various levels of unemployment. Graphically, this implies that the constrained export supply curve has a horizontal segment that corresponds to the Rybczynski segment of the constrained PPF. In Figure

${ }^{6}$ An alternative way of seeing this is to note that $\beta\left(h^{*} ; H^{w}, L^{w}\right)$ is linear homogeneous in $H^{w}$ and $L^{w}$ for a fixed $h^{*}$, and that opening to America is the same as doubling the world endowments (since Europe absorbs all of the unemployment). 
4 we depict this along with the American import demand curve for the case in which the countries are otherwise identical.

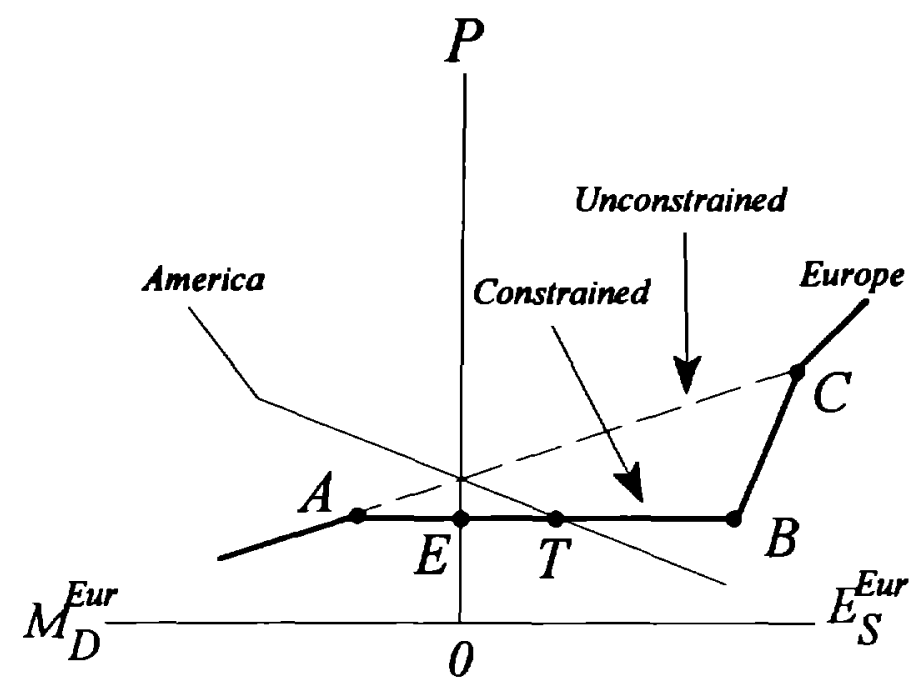

\section{Figure 4 European Unemployment Props up} American Wages

We now consider perturbations in the position of the American import demand curve, and consider their implications for unemployment and wages. So long as the American import demand curve cuts the export supply curve of Europe between $A$ and $B$, the equilibrium price will be $P^{*}$, so the wage will be $w^{*}$. In all such cases, were Europe to abandon the minimum wage policy, both European and American wages would fall in the free trade equilibrium. The effect of trade with America on European unemployment depends on whether the American import demand curve cuts the European export supply curve in the region $T B, E T$, or $A E$. If the equilibrium is in the region $T B$, then European unemployment will more than double, reaching its maximum at $B$. If in the region $E T$, European unemployment will be higher than in autarky, although at less than the double rate. If, instead, the equilibrium is in the region $A E$, then trade with America actually 
lowers European unemployment. It continues to be true in all three cases, though, that under free trade high American wages depend on the European minimum wage policy fully as much as European wages do.

\section{Shocks From the South: Implications for Europe and America}

The impact of growing trade with developing countries on labor markets in developed countries has been a source of great concern. It was at the heart of the vigorous opposition of the AFL-CIO to the North American Free Trade Agreement, and has figured prominently in the presidential campaigns of Ross Perot and Patrick Buchanan. Correlate concerns have been raised over rapid integration of Eastern Europe into the markets of the European Union.

The evidence for the growing trade, particularly in manufactures, is indisputable. In the period 1970-1990, the LDC share in manufactured imports of the United States and Europe more than doubled -- rising to more than a third for the United States [Freeman (1995)].

Correspondingly, the share of manufactures in total non-fuel exports from LDCs rose from less than one-fourth in 1970 to nearly three-fourths by 1989 [Wood (1994)].

However, what role -- if any -- this played in the factor market developments in Europe and America is still in contest. Wood (1994) has been the strongest proponent of the view that trade with the LDCs has mattered. Qualified support for this view has come from Leamer (1995). By contrast, Krugman and Lawrence (1993) have argued forcefully that the volume of trade is insufficient to account for relative wage movements in the United States. Similarly, Modigliani $(1995$, p. 7$)$ insists that the argument that increased trade with developing countries raised unemployment in Europe is "nonsense, reflecting economic illiteracy." 
Krugman (1995) examined the impact of a trade shock on a minimum wage Europe and a flexible wage America, concluding that it would raise unemployment in the former and reduce wages in the latter. However his study, on a theoretical plane, belongs to the category earlier identified as "comparative." That is, he examines this one country at a time. As we will see, the results change importantly when we turn to a global approach, in which Europe and America exist within the same world economy.'

We begin again with a flexible wage America, and a minimum wage Europe. For simplicity, and without loss of generality, we shift our base case to consider that in which $P^{*}$ is the American autarky price. This is also the European autarky price with the minimum wage in place. And so when free trade is allowed between America and Europe, $P^{*}$ is the equilibrium price. Europe has the same level of unemployment as in autarky, and both have the same wages in autarky as under free trade.

We now consider the introduction of a previously isolated region, which we will call the NICs, to the American and European free trade system. Assume that at prices $P^{*}$, the NICs are importers of the good $X$. Our concem will be to trace through the implications of this for Europe and America. In our diagram, this can be represented as a rightward shift of the joint AmericanNIC import demand curve. However, given Europe's commitment to its minimum wage, the world price $P^{*}$ does not change (Figure 5).

${ }^{7}$ This comparative theoretical approach is at work as well in an argument by the Center for Economic Policy Research (1995, p. 53). They argue that evidence, as in Lawrence and Slaughter (1993), exculpating Stolper-Samuelson in America, likewise refutes claims that trade with the NICs may have raised unemployment in Europe. However, as the discussion here makes clear, one reason that increased trade with the NICs may not account for falling wages in America is precisely that it does raise unemployment in Europe. 
At an unchanged world price, the American import demand is unchanged. So the US absorbs none of the imports from the NICs. American wages continue to be protected by the European commitment to a high wage policy. In Europe, by contrast, there will be a surge of imports from the NICs.' The impact of this is similar to that analyzed above. Given the European commitment to a high wage policy, this will not show up in reduced wages, but rather in higher unemployment.

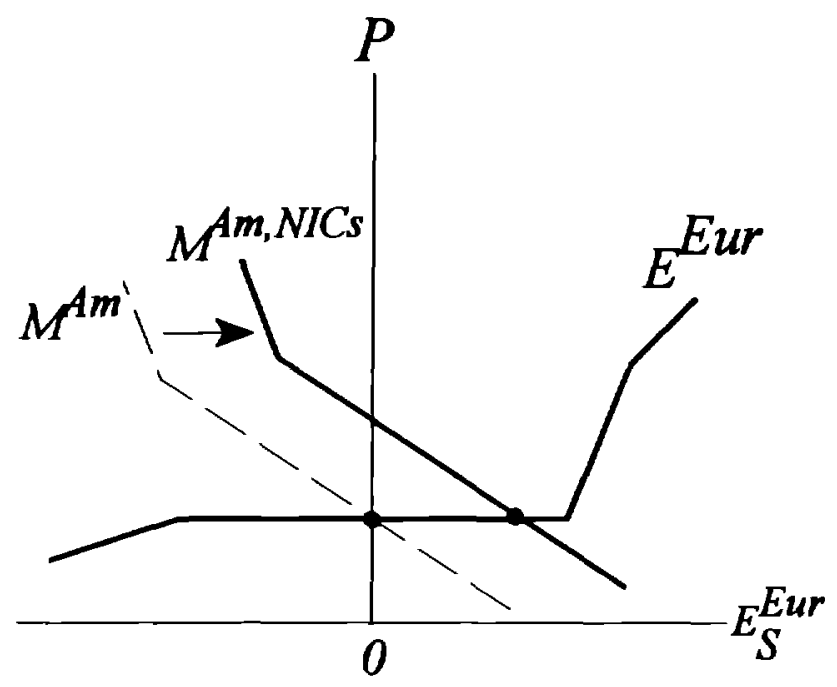

Figure 5 Entry of the NICs to the Global Economy

This integrated global economy presents an important contrast with the results of Krugman (1995). There he treated the American and European cases as though they were part of different global economies. However, as we see here, the links via goods trade are crucial for

The actual pattern of trade -- whether NICs deliveries are to America or Europe -- is inconsequential. The important point is that the price $\mathrm{P}^{*}$ defines the world net offer to Europe. Europe must absorb this net offer to maintain the price $\mathrm{P}^{*}$, and so accept the employment consequences. 
understanding the broader story. So long as Europe maintains a commitment to both free trade and a high wage policy, America is fully insulated from the NIC shock.

As this suggests, the appearance of the NICs might severely strain Europe's commitment to both a high wage policy and free trade. We will consider here the consequences for Europe and America of European restrictions on imports. We will analyze this for the case of a tariff, although alternative policies would have similar implications.

Assume, then, that Europe imposes a tariff on imports of $Y$, while maintaining its commitment to the wage $w^{*}$. The latter commitment is equivalent to maintaining its domestic price at $P^{*}$. Hence so long as European imports are weakly positive the world relative price of $Y$ must fall below $P^{*}$ by exactly the amount of the tariff. The tariff has two effects in Europe. It raises revenue proportional to the remaining imports, and it attenuates the negative employment effects of the NIC shock. With the higher relative price of $X$ resulting from Europe's trade restrictions, America experiences a surge of trade with the NICs. Moreover, the free trade, flexible wage America finds that the resulting higher price of $X$ has served to depress wages $a$ la Stolper-Samuelson. Of course America suffers no unemployment.

In sum, the appearance of the NICs gives rise to a trade shock. America is fully insulated from this shock as a result of Europe's commitment to a high wage policy. Europe, by contrast, finds the costs of this policy escalating sharply as it is forced to endure ever higher levels of unemployment to sustain the high wages. Its commitment to maintaining both free trade and high wages is under assault. If it responds by implicitly or explicitly raising barriers to the NICs' exportable (Y), then trade with the NICs is shunted toward America and the world price of the labor intensive good falls. By Stolper-Samuelson this pulls the American wage down. 
18

\section{Global Labor Supplies, European Unemployment}

\section{A. Discussion}

Leading labor economists have identified cross-country differences in the evolution of the labor force as an important explanatory factor in the divergent evolution of wages between continental Europe and the United States and United Kingdom. The underlying theoretical framework for these studies makes the acknowledged "stark" assumption of a steady trend in the growth of the skill intensity of labor demand. Under this assumption, a decline in the growth rate of the skill intensity of the labor force will induce a rise in the relative wages of the skilled. If the degree of substitutability between skilled and unskilled is sufficiently low, then these supply changes could account for all -- even more than all -- of the observed rise in the skill premium in the United States. In any case, the story matches reasonably well the experience of the United States, Britain, Japan and France [Katz and Murphy (1992), Katz, et. al. (1995)].

As insightful as this line of research has been, it would be more satisfying to consider this in a theoretical framework in which the cross-country structure of labor demand is endogenous. It might seem obvious that cross-country differences in the levels and growth rates of relative factor supplies should help to explain differences in relative wages. However, this need not be true when countries are linked by commodity trade. In fact, the absence of such a relation is the central message of Samuelson's Factor Price Equalization theorem (1949). Under the conditions in which that theorem is valid, the structure of relative wages depends on the evolution of the global labor force. ${ }^{9}$ However cross country differences in the composition or growth rates of the labor force

${ }^{9}$ In fact, this extends to a more general setting. It is straightforward to write down a model in which only a subset of the world enjoys factor price equalization [Davis, Weinstein, et.al. 
will contribute nothing to an understanding of divergent wage trends. Given that we have seen that our model with unemployment likewise yields factor price equalization, we can likewise conclude that differential labor force growth will not help to account for divergent wage patterns. $^{10}$

Although changes in relative factor supplies will not play a role in accounting for crosscountry differences in relative wages, they will be essential for understanding the evolution of unemployment in Europe. There will be a correlate to the Factor Price Equalization theorem: The level of European unemployment depends on global -- not local -- factor supplies. One consequence of this is that dramatic changes in American factor accumulation -- the shifts due to baby booms and busts -- may leave their most profound mark not on American but European labor markets. By contrast, the unemployment rate in Europe will depend importantly on where factor accumulation occurs. The conditions under which European unemployment falls are less stringent when factor accumulation is in Europe than in America.

The model also features an important asymmetry. The fixed European minimum wage insulates America from all shocks caused by factor accumulation in Europe. But the reverse is not true. Factor accumulation in America has very profound effects on Europe.

(1996)]. Subject to the general restrictions underlying FPE [see Dixit and Norman (1980)], the site of endowment changes among those sharing FPE matters neither for comparative nor absolute wages.

${ }^{10}$ It is tempting at this juncture to dismiss the factor price equalization framework by noting that in fact there have been divergent wage trends. This would suggest investigating alternative frameworks in which local relative factor supplies do matter for local relative wages. This is a promising direction of research, but not that pursued here. As we saw in Section III, one path towards accounting for the divergent trends is to introduce differential trade policies. Davis (1996a,b) considers alternative accounts, including differential patterns of local technological change and cross-country differences in the evolution of public finance. 
One striking example concerns the immigration of unskilled labor to America. Consider the case of the Mariel boatlift, which raised the labor force in Miami by seven per cent. Card (1990) has demonstrated that this had no appreciable impact on wages or unemployment in Miami. This is just as our model would predict. However, the model suggests that the drastic effects should have been found not in Miami, but Madrid and Marseilles. In fact, the model predicts that European national income will fall dollar-for-dollar with the rise in American national income, while European unemployment rises one-for-one with the incremental employment of the Marielitas. ${ }^{11}$ Having committed itself to the fixed wage, Europe must brave the potentially harsh winds of external shocks.

In the conventional Heckscher-Ohlin framework the central theorem dealing with endowment changes is that of Rybczynski. It says that at fixed goods prices, an increase in the endowment of a factor leads to a more than proportional increase in output in the sector that uses that factor intensively, and a contraction in the other sector. At the initial equilibrium price this would be expected to create an excess supply of the good that uses that factor intensively, lowering its equilibrium relative price, and by Stolper-Samuelson reducing the retum to that factor. In the conventional setting, at fixed prices, changes in the endowment of one country have no effect on output supplies in the other.

${ }^{11}$ The story will be exactly true if Cuba is thought of as being fully isolated from world markets and if the emigrants are homogeneous with American unskilled labor. A qualitatively similar, though more nuanced, story emerges if migration is endogenous, but comes from a country integrated into the global trading system. I plan to examine this in future work. 


\section{B. Derivation of Principal Results}

We now turn to a systematic evaluation of the impact of factor accumulation in our present model. We begin by considering the implications for the global economy, and then turn to examine how these effects are distributed according to where the accumulation takes place. We continue to assume throughout that Europe maintains the minimum wage at $w^{*}$ and that both economies are diversified.

Several observations will make the derivation of the results more transparent. Europe's commitment to maintain the high wage $w^{*}$ is likewise a commitment to maintain a domestic relative price $P^{*}$, as given by the zero profit conditions for the two goods. With free trade, this will also be the world relative price. We saw above that the common goods prices yield factor price equalization. Cost-minimizing firms with identical technologies will then pick the same factor intensities in both countries, denoted $h_{X}$ and $h_{Y}$. With $P^{*}$ fixed in all equilibria that we consider, these factor intensities will also be fixed. Because of identical and homothetic demand, $P^{*}$ also fixes the ratio in which $X$ and $Y$ will be consumed. This implies directly that world output at equilibrium must be supplied in the same proportion. This absorbs factors in a certain proportion, denoted by $h^{*}$. This represents both the minimum skill-intensity that the world economy needs to yield the wage $w^{*}$ in a flexible wage world, and the actual skill-abundance of total employed factors in the world with at least one economy with a minimum wage at $w^{*}$. Unemployment will arise when the actual world endowment, $h^{W}$, is such that $h^{W}<h^{*}$. The Rybczynski Theorem is usually stated for a fixed exogenous price. Here we consider the case in which the price is held fixed by the commitment of Europe to maintain the minimum wage. Finally, recall that unemployment can be written as $U^{*}=L^{W}-H^{W} / h^{*}$. 
Although our principal interest is in the effects of factor accumulation, it is convenient to begin with a version of the Heckscher-Ohlin theorem for trade between a flexible wage economy and a minimum wage economy. Let $\boldsymbol{h}^{4}$ denote the skill to labor ratio in flexible wage America. Given a minimum wage $w^{*}$ that binds where applied, and that both economies are diversified, the world employment ratio of skill to labor is fixed at $h^{*}$. The flexible wage America will be an exporter of the skill intensive good if and only if $\boldsymbol{h}^{\boldsymbol{4}}>\boldsymbol{h}^{*}$. The minimum wage Europe will have a complementary trade pattern. The easiest way to see how the Heckscher-Ohlin theorem works here is simply to delete Europe's unemployed from Figure 2. They do not contribute income, so consume only from transfers that they will spend in the same pattern as those employed. Having done this, our diagram just becomes the conventional Heckscher-Ohlin model, although now in terms of employed factors.

We now turn to the results concerning accumulation of factors. A rise in the world endowment of skill expands the output of both goods proportionally. Employment rises to maintain the ratio of employed factors at $h^{*}$. If the skill accumulation occurs in flexible wage America, it will have conventional Rybczynski effects, raising the output of $X$ more than proportionally and decreasing the local output of $Y$ [see Figure 6]. However this also affects Europe, which has a rise in employment at rate $U U^{\prime}=\Delta N=\Delta H^{A} / h^{*}$. It has Rybczynski effects skewed the other direction, with output of $Y$ rising more than proportionally, and output of $X$ declining. The net impact of the output changes in the two countries must, as noted, raise output of $X$ and $Y$ in proportion to the initial world output. 


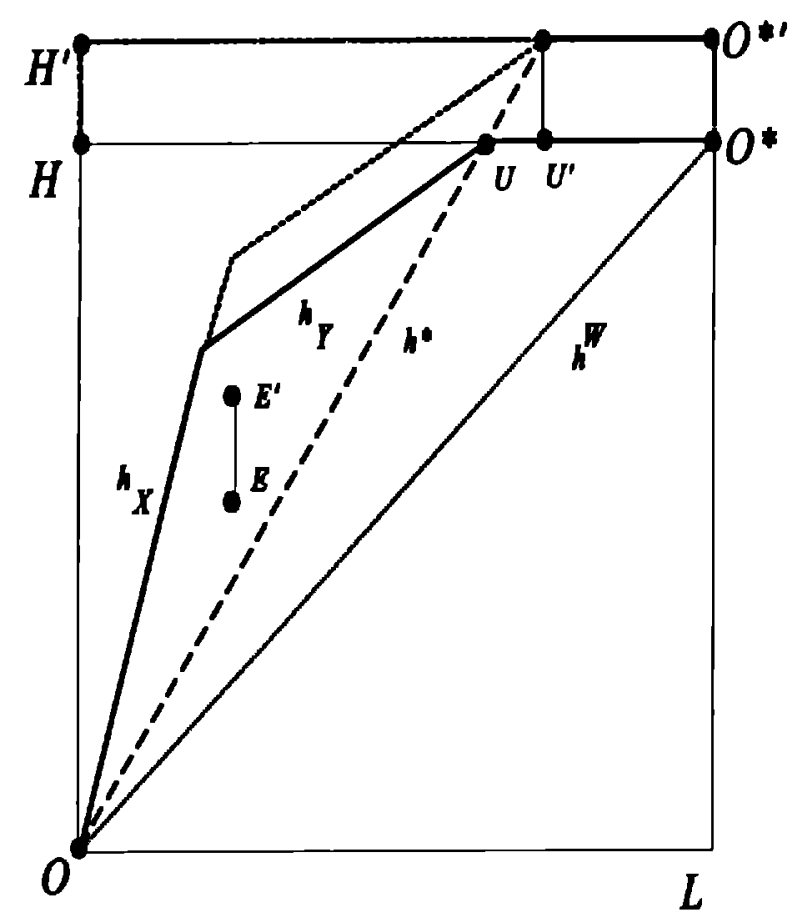

Figure 6 Skill Accumulation in Flexible Wage America

If instead the skill accumulation occurs in minimum wage Europe, we have a very different picture. In Europe we fail to have conventional Rybczynski effects. Incipient excess supply of $X$ threatens to raise the wage above $w^{*}$ at the initial level of employment. This allows employment to rise by $\Delta N=\Delta H^{E} / h^{*}$. That is, total employment of factors in Europe has risen in exact proportion to total initial employment in the world as a whole, $h^{*}$. Thus, output in Europe expands proportional to initial world output. America is entirely unaffected, as its net trade vector is fully determined by the constant price ratio $P^{*}$.

Now consider the effect of accumulation of unskilled labor. At the global level, unemployment rises by the full increment to the labor force. There is no effect on global output. If the accumulation occurs in minimum wage Europe, unemployment rises directly with no effect on 
output in either country. However, if accumulation of unskilled labor happens in America, there are very dramatic shifts [see Figure 7]. America continues to have conventional Rybczynski effects, raising the output of $Y$ more than proportionally, and reducing the output of $X$. Income in America rises linearly, so $\Delta I^{A}=w^{*} \Delta L^{A}$. Europe is also strongly affected. In fact, European unemployment rises one for one with accumulation of unskilled labor in America. And European income falls dollar for dollar with the rise in American income. Its shift in output exactly offsets that of America, so that global output is unchanged.

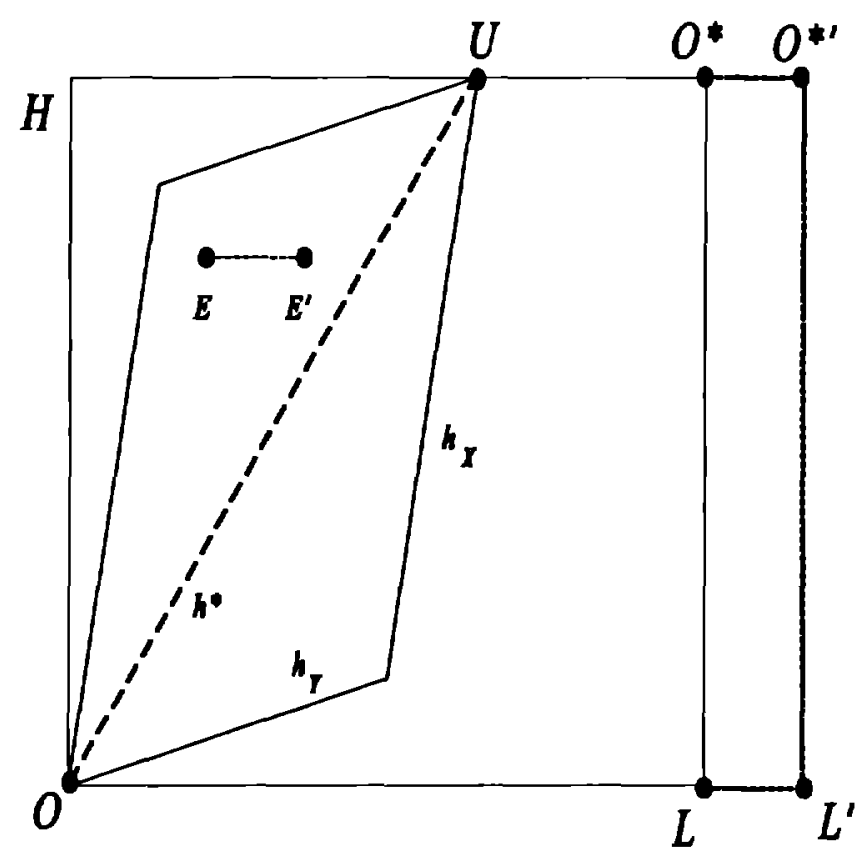

Figure 7 Unskilled Labor Accumulation in America 


\section{The Reagan-Mitterrand Paradox}

So far we have treated the policy choice of flexible wages versus a minimum wage as determined exogenously. Yet these institutions have changed over time. One of the most noteworthy aspects of this change has been the sharp decline in private sector union membership in the United States in recent decades. The constellation of forces that led to declining strength of labor in the US and a continuing strength in Europe are numerous. In this section we consider a highly stylized version of this social choice problem. We imagine that the choice of factor market institutions is the work of a single decisionmaker representing each "country" -- Reagan in America, and Mitterrand in Europe.

The choice each must face is whether to impose a minimum wage at $w^{*}$ or to maintain a fully flexible wage. Under this assumption, and given the symmetry of underlying economic conditions, there are four types of payoffs that serve as arguments to their social welfare function:

F: Define $F$ to be the symmetric payoff when both choose a flexible wage policy.

M: Define $M$ to be the symmetric payoff when both choose to impose the same binding minimum wage. We take as the central case that in which this results in an even division of the resulting unemployment. ${ }^{12}$

T: This is the payoff when a country that has flexible wages while the counterpart has a minimum wage. "T" reflects the fact that this country comes out on top in the bargain, enjoying the higher wage without having to suffer unemployment.

\footnotetext{
12 This is the division that one would anticipate if all other aspects of symmetry were preserved but European and American goods were imperfect substitutes. One can consider our case as the limit of a sequence of economies in which the substitutability of European and American goods rises toward infinity.
} 
B: This is the payoff to a country when it has a minimum wage while the counterpart has a flexible wage. " $B$ " reflects the fact that this country comes out on bottom in the bargain, enjoying the higher wage but bearing the burden of high unemployment for both countries.

\section{CHART ONE}

\begin{tabular}{|c|c|c|}
\hline Reagan & & \\
Mitterrand (Eur, Am) & Flexible Wages & Minimum Wage \\
\hline Flexible Wages & (F, F) & (T, B) \\
\hline Minimum Wage & (B, T) & (M, M) \\
\hline
\end{tabular}

We begin with a few general observations. First, both Reagan and Mitterrand must always rank $T>M$. That is, if a country can maintain the wage $w^{*}$, it always prefers that the other country bear the burden of unemployment that supports it. Thus, even if each in autarky would choose to impose the minimum wage, this game will never support a trade equilibrium in which both maintain the minimum wage. As well, it will always be the case that $M>B$. That is, one would always prefer to share the unemployment burden of maintaining the wage $w^{*}$ rather than have to bear it alone. It will also be true that $T>F$. This is equivalent to the observation that America enjoyed (conventional) gains from trade in our general equilibrium above, and that on top of this $w=w^{*}$ for the country with outcome $T$. Thus for both countries in all cases, $T \succ F$, and $T>M \succ$ $B$. The games thus differ only in two dimensions: where in this ordering below $T$ that $F$ goes for each, and whether the rankings by Reagan and Mitterrand are the same. In the following we will restrict our attention to pure strategy equilibria on the grounds that major institutional features of the labor market cannot be changed from day to day, or perhaps even from year to year. 
We now consider the equilibria resulting from the game between Reagan and Mitterrand. Chart Two emphasizes two points. The first concerns the type of equilibria that emerge. Here there are only two basic types. In one of them, both America and Europe allow a flexible wage. In the other type of equilibrium, one country bears the entire burden of unemployment for sustaining the high wage. Notice that both countries imposing a minimum wage is not an equilibrium. The second point from Chart Two is that the type of equilibrium is determined by the countries' relative rankings of the flexible outcome, $F$, and the outcome of bearing alone the cost of supporting the minimum wage, $B$.

\section{CHART TWO}

\begin{tabular}{|c|c|c|}
\hline Reagan & & \\
Mitterrand (Eur, Am) & $\mathrm{F} \succ \mathrm{B}$ & $\mathrm{B} \succ \mathrm{F}$ \\
\hline $\mathrm{F}>\mathrm{B}$ & $(\mathrm{F}, \mathrm{F})$ & $(\mathrm{T}, \mathrm{B})$ \\
\hline $\mathrm{B}>\mathrm{F}$ & $(\mathrm{B}, \mathrm{T})$ & $(\mathrm{B}, \mathrm{T})$ or $(\mathrm{T}, \mathrm{B})$ \\
\hline
\end{tabular}

We will consider the characterization that America has flexible wages relative to those in Europe as a suggestion that Reagan ranks the equilibrium in which both have flexible wages as preferable to one in which America ends up on bottom. In this case, flexible wages are a dominant strategy for Reagan. However, we may leave open the question of whether Mitterrand ranks $F \succ$ $B$ or the reverse. If Mitterrand does rank $F>B$, then the equilibrium will feature flexible wages in both countries. This includes the case in which both rank $M>F>B$. This would be a case in which each would impose the minimum wage in autarky, but both tum to flexible wages under trade. In common terms this may be viewed as a "race to the bottom." 
However, a race to the bottom is not a necessary outcome. Nor may it be the most likely outcome. Our earlier discussion suggested that Mitterrand may have a stronger commitment to maintaining the minimum wage. Thus Reagan ranks $F>B$, and Mitterrand the reverse. In this case, the equilibrium features a flexible wage in America and a minimum wage in Europe. Where do the unskilled end up better off? This is precisely the case analyzed earlier. They end up better off in Reagan's America than in Mitterrand's Europe. The reason is that they both enjoy the same high wage, but European workers must endure the unemployment that sustains it.

\section{Conclusion}

This paper has one overarching message. Even when factor markets are strictly local, with idiosyncratic institutional features, they cannot be considered in isolation when goods markets are global. This strongly suggests the importance of a unified "global" approach to explaining recent factor market developments in Europe and America. This will be an important complement to existing studies, which are either of individual countries or comparative.

A striking example of the importance of the global perspective emerges in the contrasting effects of trade on a flexible-wage America and a minimum-wage Europe. In our central example, trade doubles the European unemployment rate while leading American wages to converge to the high European level.

Moreover, commodity trade leads local institutional features to have important spillover effects on other countries. These go far beyond the simple general equilibrium fact that they will affect the level of wages and the composition of production. They may fundamentally alter the nature of a country's relation with the international environment. For example, if Europe and 
America are both flexible wage economies, then the entry of the NICs to world markets may depress wages in each. However, we saw that when Europe imposed a minimum wage, it absorbed the full impact of the NIC shock and wholly insulated America from its effects. That is, a local European institutional feature has sharply altered America's relation to the trading world.

The local institutional features may likewise introduce important asymmetries in the relations between the countries. As noted, America is wholly insulated from external shocks, including factor supply shocks in Europe. By contrast, factor supply shocks in America have very powerful effects in Europe. A striking example occurs with a rise in the unskilled labor force in America. This raises American income, yet lowers European income dollar for dollar, while raising European unemployment one for one.

The importance of considering the links via commodity trade is particularly important when thinking about the evolution of wages. In spite of important differences in factor market institutions, which in a closed economy would induce differences in factor prices, goods trade here insures full factor price equalization. Perversely, labor ends up worst off in the country nominally most supportive of its aspirations.

These powerful effects of trade suggest that countries must consider international markets when designing local labor market institutions. When we allow for a strategic choice of labor market institutions, we see that it is possible that two countries may resort to a low flexible wage under trade even if in autarky they support a minimum wage. In common terms, this may be viewed as a "race to the bottom." However this is not a necessary result of integration of global goods markets. Nor, perhaps, does it seem to be the one most in accord with stylized accounts of American and European experience. This account, which emphasizes the relatively strong 
European commitment to labor, may actually signal that American labor has received a free ride -high wages supported by unemployment in Europe.

This paper has derived these results in a stylized model. Care should be taken in reading these results too readily into actual historical experience. Nonetheless the issue that it raises of the powerful interaction between local factor market institutions and global goods markets are no doubt very important. And the results are sufficiently provocative to warrant closer examination. 


\section{References}

Berman, E., Bound, J. And Giliches, Z. (1994) "Changes in the Demand for Skilled Labor within US Manufacturing: Evidence from the Annual Survey of Manufactures," Quarterly Journal of Economics, May, 109, 367-97.

Brecher, Richard A. (1974a) "Minimum Wage Rates and the Pure Theory of International Trade," Quarterly Journal of Economics, 88, No. 1, 98-116.

Brecher, Richard A. (1974b) "Optimal Commercial Policy for a Minimum-Wage Economy," Journal of International Economics, 4, No. , 139-149.

Card, David (1990) "The Impact of the Mariel Boatlift on the Miami Labor Market," Industrial-and-Labor-Relations-Review; 43(2), January, 245-57.

Center for Economic Policy Research [CEPR] (1995) Unemployment: Choices for Europe, in the series "Monitoring European Integration 5," London: CEPR.

Davis, Donald R. (1996a) "Technology, Relative Wages, and Unemployment in a Global Economy," mimeo, Harvard University.

Davis, Donald R. (1996b) "Unemployment and Finance of a Social Safety Net in a Global Economy," mimeo, Harvard University.

Davis, Donald R., Weinstein, David E., et al. (1996) "The Heckscher-Ohlin-Vanek Model of Trade: Why Does it Fail? When Does it Work?" mimeo, Harvard University.

Dixit, Avinash K. and Norman, Victor F. (1980) Theory of International Trade, Cambridge: Cambridge University Press.

European Commission, Directorate-General for Employment, Industrial Relations and Social Affairs (1995) Employment in Europe, Brussels: ECSC-EC-EAEC.

Freeman, Richard B. (1995) “Are Your Wages Set in Beijing?", Journal of Economic Perspectives, Summer, 9:3, 15-32.

Freeman, Richard B. and Katz, Lawrence F. eds. (1995) Differences and Changes in Wage Structures, Chicago: University of Chicago.

Katz, Lawrence F., et.al. (1995) "A Comparison of Changes in the Structure of Wages in Four OECD Countries," in Freeman, Richard B. and Katz, Lawrence F. eds. (1995) Differences and Changes in Wage Structures, Chicago: University of Chicago.

Krugman, Paul (1995) "Growing World Trade: Causes and Consequences," mimeo Stanford University, prepared for the Brookings Panel on Economic Activity, April 6-7, 1995.

Leamer, Edward (1995) "In Search of Stolper-Samuelson Effects Between Trade and US Wages" mimeo, Yale and UCLA.

Leamer, Edward (1994) "Trade, Wages and Revolving Door Ideas" NBER Working Paper No. 4716, April.

Modigliani, Franco (1995) "The Shameful Rate of Unemployment in the EMS: Causes and Cures," mimeo.

Mussa, Michael A. (1979) "The Two-Sector Model in Terms of its Dual: A Geometric Exposition," Journal of International Economics, 9, No. 4, 513-526.

Nader, Ralph, et al. (1993) "Introduction: Free Trade and the Decline of Democracy," in The Case Against Free Trade: GATT, NAFTA, and the Globalization of Corporate Power, San Francisco: Earth Island Press. 
Samuelson, Paul A. (1949) "International Factor Price Equalization, Once Again," reprinted in Jagdish Bhagwati, ed., International Trade: Selected Readings, 2nd ed., (1987) Cambridge: MIT. 